\title{
Effect of test year, parity number and days in milk on somatic cell count in dairy cows of Los Ríos region in Chile
}

\author{
Kiala B. Sebastino ${ }^{\mathrm{a}}$, Héctor Uribe ${ }^{\mathrm{b} *}$, Humberto H. González ${ }^{\mathrm{b}}$
}

\begin{abstract}
In Chile, most dairy cattle are located in the southern region of the country, where the largest volume of milk is produced. This study aimed to quantify changes of somatic cell count (SCC) over 20 years in 11 herds of the Los Ríos region and to assess the effect of parity number, days in milk, milk yield, and milk fat and protein content on SCC. A database of approximately 277,709 observations based on 10,363 cows from 11 herds of the area was used. Data were gathered from 1998 to 2018. Outliers and inconsistent observations were eliminated. Multiple linear regression was used to model SCC on fixed variables such as test year, parity number, test season, and stage of lactation; covariables included in the model were milk yield, milk fat and protein yields, and milk urea concentration. There were statistically significant associations among SCC and all independent variables included in the model. Regarding parity number and stage of lactation, they increased along with SCC. SCC was higher in warmer months and, as SCC increased, the yield decreased. It was concluded that as test year increased, SCC decreased, indicating that the mammary gland health improved and the quality of the milk was better.

Key words: milk, test day, mastitis, microbiological quality of milk.
\end{abstract}

\section{INTRODUCTION}

Most of the milk produced in the southern regions of Chile is purchased by dairy companies and, since 1995, these companies have demanded higher quality standards to obtain uniform and top-quality dairy products, otherwise they would not be able to process such products (Carrillo and Vidal 2002). At farm level, to develop and keep plausible milk quality standards, it is necessary to use a comprehensive predictor of the mammary gland health status, as it is the case of somatic cell count (SCC) (McDougall et al 2009).

The cow mammary gland is a dynamic and complex organ composed of various cell types that act together aimed to milk synthesis and secretion, however, during bacterial or traumatic challenge, some of the endothelial cells divert their lactation function to protect the tissue from damage by initiating an inflammation process (Ryman et al 2015). Somatic cells (from the Greek "somatikós", meaning "from the body") contained in milk are mainly leucocytes and their movement towards the affected tissue, at the beginning of a mammary gland inflammation process, is regulated by endothelial cells (Ryman et al 2015).

In milk from a healthy mammary gland, leucocytes consist of several different cells, such as macrophages (60\%), neutrophils (15\%), and lymphocytes (25\%) (Brito et al 1997). As well as leucocytes, milk somatic cells are also comprised by mammary gland endothelial cells; leucocytes

Received: 14.05 .2019 .

Accepted: 12.11.2019.

anstituto de Ivestigação Veterinária, Huambo, Angola.

bepartamento de Producción Animal, Facultad de Ciencias Agronómicas, Universidad de Chile, Santiago, Chile.

*Corresponding author: H Uribe; hector.a.uribe@gmail.com move from the bloodstream toward the mammary gland as a response to a physical, chemical or infectious aggression (Ryman et al 2015). The inflammatory process resulting from bacteria or traumatic aggression attracts leucocytes, and when it is extremely intense there is an exaggerated presence of cells and other substances, also coming from the bloodstream, that move into the mammary gland and consequently into milk (Brito et al 1997).

For milk testing organizations, SCC recording is a standard procedure used to estimate mammary gland health status (Hernández and Bedolla 2008) because it provides information regarding the severity of the mammary tissue inflammation in each quarter, and milk samples can also come from the milk storage tank at the farm (Curbelo 2007).

Mastitis diagnosis based on SCC considers that a healthy mammary gland, producing normal milk, can contain up to $100,000 \mathrm{cell} / \mathrm{mL}$, milk with 100,000 to $200,000 \mathrm{cell} / \mathrm{mL}$ is considered suspicious, while SCC over 200,000 cell/ $\mathrm{mL}$ is an indication of subclinical mastitis presence and is considered abnormal milk (International Dairy Federation 1997, Hernández and Bedolla 2008). Several factors affect milk SCC, Hernández and Bedolla (2008) indicated that in cows that have never had a mammary gland infection their milk SCC varies from 20.000 to $50.000 \mathrm{cell} / \mathrm{mL}$.

Higher environmental temperature and humidity are responsible for increasing bacteria content in manure; therefore, cows housed in dirty barns where the mammary gland is in direct contact with manure are more prone to acquire mastitis. Consequently, milk SCC is affected by the season, being lower in cold $\left(1.10 \times 10^{5}\right.$ cell $\left./ \mathrm{mL}\right)$ and hot and dry weather $\left(1.11 \times 10^{5}\right.$ cell $\left./ \mathrm{mL}\right)$ in contrast with climatic periods of high temperature and humidity $\left(2.14 \times 10^{5}\right.$ cell/ $\mathrm{mL}$ ) (Alvarado 2006).

A study conducted by Fox (2009), showed that initial milk SCC is low and subclinical mastitis and mammary gland infection severity is lower in heifers when compared 
to multiparous cows, and it also showed that SCC is low immediately after calving demonstrating a minimal level of subclinical mastitis incidence. According to Nyman et al (2009), cows showing clinical mastitis and high SCC during their first lactation are at higher risk of having both as recurrent problems in following lactations.

In countries where mastitis control programs are underway, results show that it is not impossible to keep SCC under control, for instance Germany, England and New Zealand reached an average SCC below 200,000 cell/mL (NMC 2013). Most of the Chilean milk is produced in the southern area of the country, with the most important dairy production regions being Araucanía, Los Lagos, and Los Ríos, where cow feeding is mainly based on pasture grazing and the production goal is switching from high yield per cow to high production of milk and milk solids per unit of land.

Chile does not have a SCC legal limit, however, dairy companies have adopted a range from 300,000 to 400,000 cell $/ \mathrm{mL}$ as the maximum limit without economic penalty to dairy farmers. Consequently, dairy companies are demanding a milk quality in accordance with the requirements of the countries where some of the Chilean milk products are being exported (Butendieck 1997). According to Kruze (2000), from 1997 to 2000 the average SCC, in southern Chile, decreased from 460,000 to 330,000 cell $/ \mathrm{mL}$ of milk. Agüero (2002) indicated that dairy farms that met sanitary standards and have in place official milk recording have made positive improvements, and their SCC average decreased from $471,000 \mathrm{cell} / \mathrm{mL}$ in 1994 to $256,000 \mathrm{cell} / \mathrm{mL}$ in 2001. Kruze (2005) indicated that Chilean SCC average was 311,000 cell/mL, while Werner (2014) reported a raw average SCC of $151,131 \mathrm{cell} / \mathrm{mL}$ of milk when analyzing 640,249 lactations from Malleco to Chiloé.

The objectives of this study were to quantify: a) SCC change across 20 years in dairy herds of Los Ríos region, b) SCC evolution across parity number, and c) SCC variation as lactation progresses.

\section{MATERIAL AND METHODS}

A database containing test day milk records of 11 herds from Los Ríos region, southern Chile was used which had 321,523 records gathered from 10,363 cows from 1998 to 2017. The records provided milk test day SCC and information on herd identification, days in milk, test day date, parity number, milk, fat and protein yield, and milk urea concentration. To remove outliers, the raw data was edited and records above and below three standard deviations from the mean were deleted. Records having SCC greater than 800,000 cell $/ \mathrm{mL}$ of milk were deleted because it was assumed that those samples came from cows with clinical mastitis.

The analyses used linear regression to model milk SCC as a function of the fixed effects of parity number, herd, stage of lactation, test day season and year, and, as a covariate, milk, fat and protein yields and urea concentration. Stage of lactation had three levels; the first level included cows starting their lactation with increasing milk yield, from 6 to 100 days in milk; the second level included cows that reached their production peak and started to decline milk yield, from 101 to 200 days in milk; and the third level included cows reaching the end of lactation with decreasing milk yields, from 201 to 365 days in milk; test day records above 365 days in milk were not included in the analysis. Test day season also had three levels, the first season included the test day records made in April, May, June, and July (autumn, winter), second season test day records were made in August, September, October and November (spring), and the third level included records made in December, January, February, and March (summer). Parity number effect had six levels as cows having six or more lactations were grouped into a single level.

SCC is a variable that does not follow a normal distribution, to approximate normality, and fulfil the assumptions invocated in statistical hypothesis testing, it was transformed to Somatic Cell Score (SCS) as described by Ali and Shook (1980), SCS=Log2 (SCC/100)+3, where: $\log 2=$ is the binary $\log$ arithm.

SCS least-square means for the year, season, parity number, and stage of lactation were estimated to quantify differences among them. The multiple regression model was:

$$
\begin{aligned}
& y_{i j k l m n}=\mu+\text { Sea }_{i}+H_{j}+\text { Year }_{k}+\text { Par }_{l}+S L_{m}+(b 1) \text { Milk }_{i j k l m}+ \\
& \left(b_{2}\right) \operatorname{Prot}_{i j k l m}+\left(b_{3}\right) \text { Fat }_{i j k l m}+\left(b_{4}\right) \text { Urea }_{i j k l m}+e_{i j k l m n}
\end{aligned}
$$

Where:

$y_{i j k l m n}=$ is a SCS test day record

$\mu=$ intercept

$\mathrm{Sea}_{i}=$ fixed effect of the $\mathrm{i}^{\text {th }}$ test day season $(\mathrm{i}=1,2,3)$

$H_{j}=$ fixed effect of the $\mathrm{j}^{\text {th }}$ herd $(\mathrm{j}=1,2, \ldots . ., 11)$

Year $_{k}=$ fixed effect of the $\mathrm{k}^{\text {th }}$ test day year $(\mathrm{k}=1,2, \ldots, 20)$

$\mathrm{Par}_{l}=$ fixed effect of the $\mathrm{l}^{\text {th }}$ parity number $(1=1,2, \ldots, 6)$

$S L_{m}=$ fixed effect of the $\mathrm{m}^{\text {th }}$ stage of lactation $(\mathrm{m}=1,2,3)$ $b_{1}, b_{2}, b_{3}$ y $b_{4}=$ regression coefficients of SCS test day on milk yield, and milk protein, fat and urea content, respectively.

$e_{i j k l m n}=$ random residual $\sim\left(0, \sigma_{e}^{2}\right)$

To conclude on the statistical significance of SCC trends across year and parity number, the estimated test day SCC least-square means were regressed on their respective levels.

Data editing and analyses were done using the Statistical Analysis System software (SAS 2000).

\section{RESULTS}

TEST YEAR

Table 1 shows the evolution of SCC from 1998 to 2017 , the raw means ranged from 129,361 (1997) to 151,518 (2017) and presented rises and falls across the years. 
Table 1. Number of observations (N), mean, standard deviation (SD), and minimum (Min) and maximum (Max) values for somatic cell count across years in dairy cattle of Los Ríos region, Chile.

\begin{tabular}{cccccc}
\hline Year & $\mathrm{N}$ & Mean & SD & Min & Max \\
\hline 1998 & 4,362 & 113,453 & 146,720 & 50,000 & 800,000 \\
1999 & 4,545 & 130,304 & 159,276 & 63,000 & 800,000 \\
2000 & 5,116 & 145,489 & 165,059 & 76,000 & 799,000 \\
2001 & 5,747 & 133,480 & 156,200 & 71,000 & 800,000 \\
2002 & 6,304 & 142,667 & 166,403 & 71,000 & 800,000 \\
2003 & 7,340 & 113,648 & 145,612 & 51,000 & 799,000 \\
2004 & 9,122 & 121,336 & 146,651 & 59,500 & 796,000 \\
2005 & 10,772 & 128,047 & 150,516 & 67,000 & 800,000 \\
2006 & 11,765 & 126,822 & 150,768 & 65,000 & 800,000 \\
2007 & 13,463 & 137,712 & 152,831 & 77,000 & 800,000 \\
2008 & 14,710 & 135,611 & 151,281 & 74,000 & 800,000 \\
2009 & 15,654 & 132,257 & 151,396 & 71,000 & 800,000 \\
2010 & 16,716 & 139,458 & 147,923 & 84,000 & 800,000 \\
2011 & 17,946 & 123,618 & 140,566 & 67,000 & 800,000 \\
2012 & 23,090 & 112,917 & 136,005 & 57,000 & 798,000 \\
2013 & 25,014 & 116,050 & 137,238 & 60,000 & 800,000 \\
2014 & 26,417 & 118,138 & 137,200 & 64,000 & 800,000 \\
2015 & 25,398 & 128,949 & 141,401 & 76,000 & 800,000 \\
2016 & 24,188 & 130,214 & 147,423 & 72,000 & 800,000 \\
2017 & 10,040 & 138,532 & 150,918 & 81,000 & 799,000 \\
\hline
\end{tabular}

All fixed effects and covariables included in the model were statistically significant and the R-squared of the model was 0.24 .

Figure 1 shows the least square means (LSM) of SCC across years, the highest SCC were seen in 2002, 2000, and 2001 while the lowest were observed in 2014 and 2016. Although the trend presented rises and falls there is a clear tendency to decrease SCC across years. The SCC LSM of the last observational years (2016 and 2017) are significantly lower than in previous years. Considering LSMs from the year 2002, when the highest LSM was estimated, they diminished from 111,228 to 70,360 cell/ $\mathrm{mL}$ (figure 1). Across all study period, the average LSM was $90,794 \mathrm{cell} / \mathrm{mL}$ of milk. The estimated single lineal regression coefficient indicated a decreasing trend of 1,633 cell/mL per each study year.

\section{PARITY NUMBER}

Figure 2 shows LSM for SCC across parity number. There is a clear and significant trend toward an increment of SCC as parity number progresses. Parity LSM were, among them, all statistically different and ranged from 55,271 to $129,451 \mathrm{cell} / \mathrm{mL}$, from first to sixth parity, respectively.

The estimated single lineal regression coefficient of LSMs on their parity number reveals that, at each increment of parity, the SCC increases by 15,605 cell $/ \mathrm{mL}$ of milk.

\section{STAGE OF LACTATION}

As previously stated, days in milk were edited into three categories: 6 to 100, 101 to 200, and 201 to 365 days in milk for lactation stages I, II, and III, respectively. Table 2 shows LSM for SCS and SCC for all three lactation stages. LSMs were statistically different and as the stage of lactation progressed the number of somatic cells in milk increased, the increment in SCC from first to the third stage of lactation was 13\% (table 2).

\section{TEST DAY SEASON}

There were significant differences among all three test day seasons, the third season, corresponding to test day observations made in the summer, had the highest SCC. On the contrary, test day observations gathered toward the end of fall to mid-winter time (first test day season) showed the lowest SCC. Least square means for first, second and third test day season were $81.4 \pm 12.5,89.3 \pm 12.5$ and $92 \pm 12.5$ cells $/ \mathrm{mL}$, respectively.

\section{MILK YIELD}

The regression coefficient of SCS on milk yield was $-0.049(P<0.05)$, which indicates that as milk yield increased SCS decreased. Regression coefficients of 


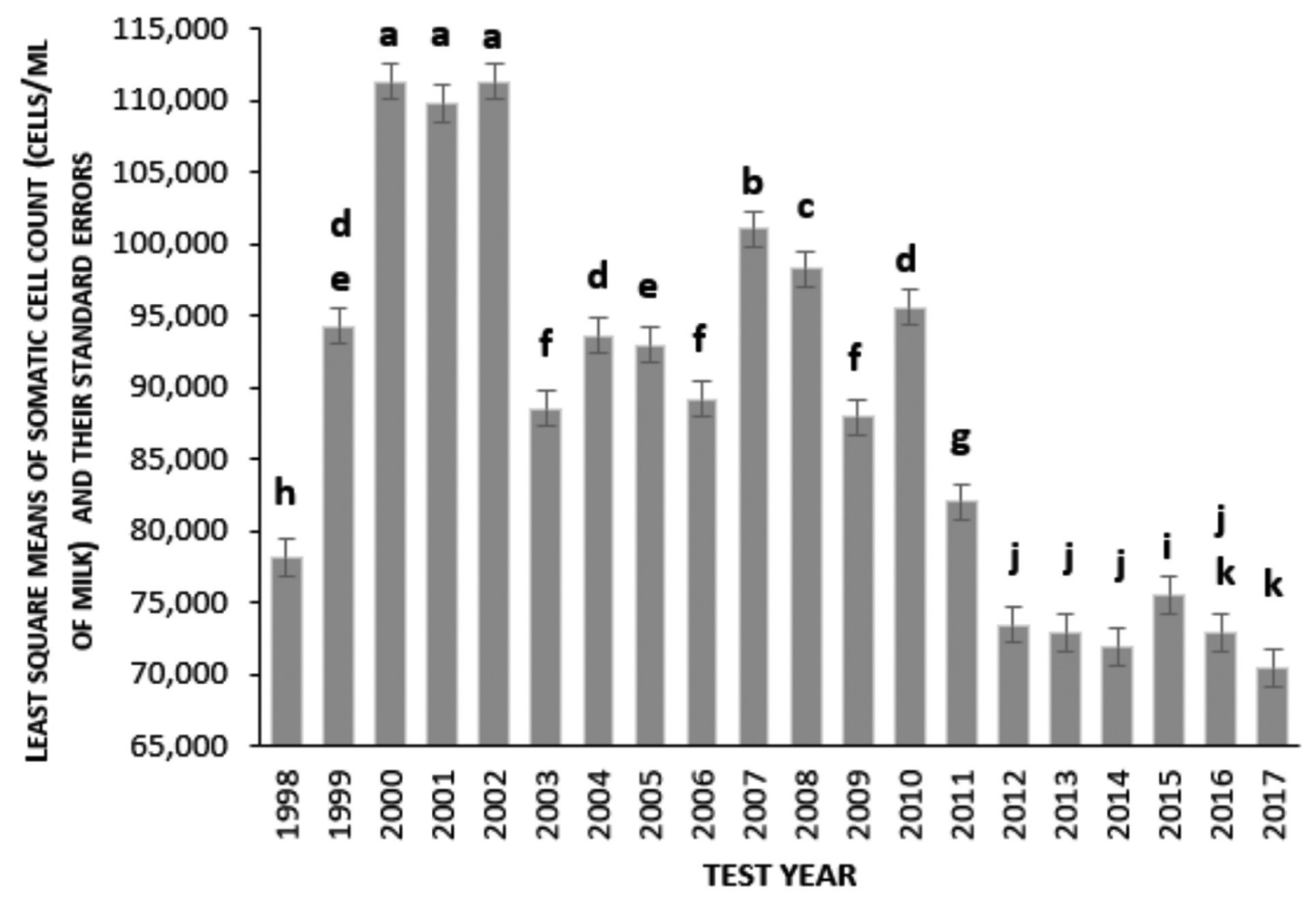

Figure 1. Least square means, and their standard errors, for somatic cell count versus test year. Means with the same letter are not significantly different $(P>0.05)$.

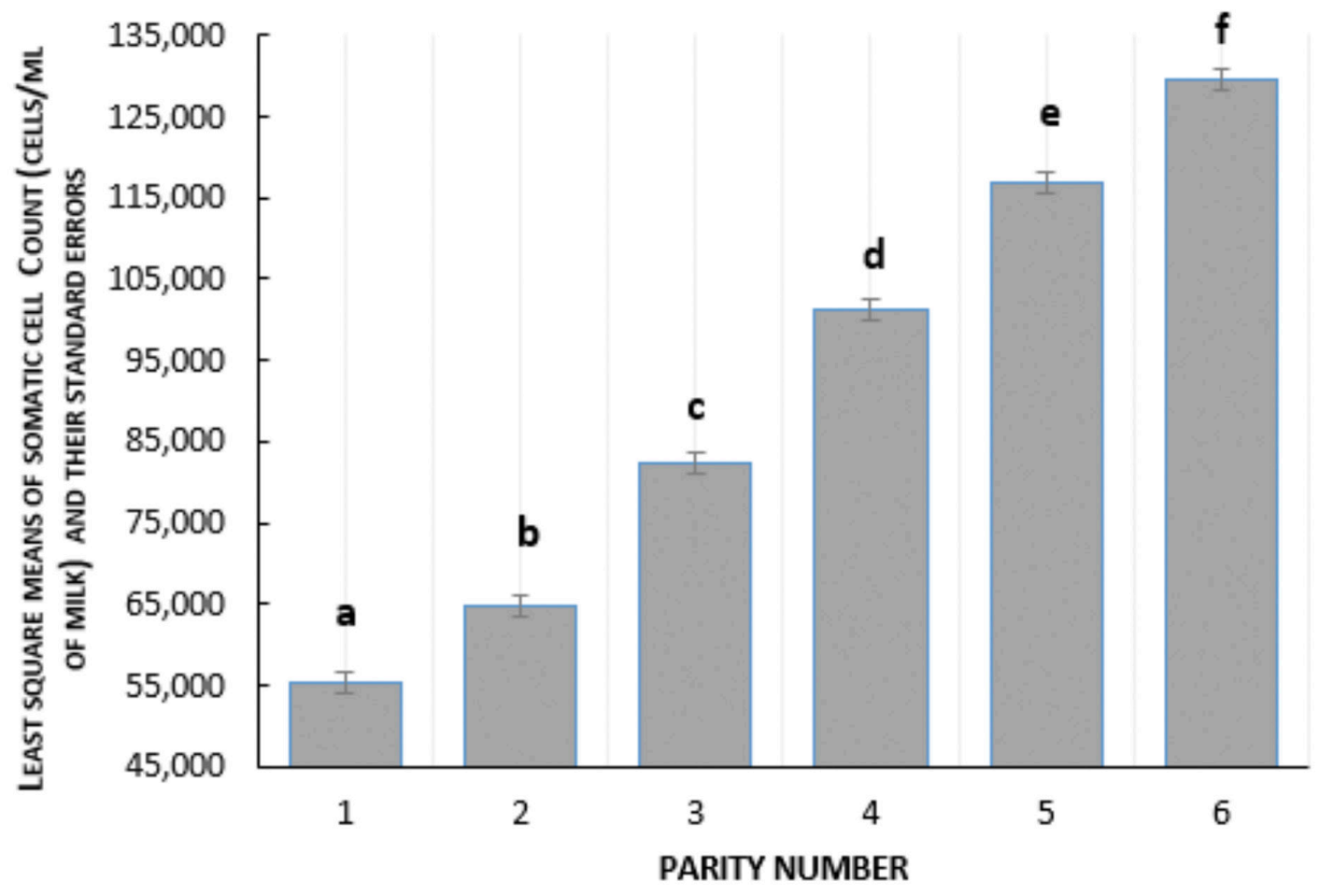

Figure 2. Least square means, and their standard errors, of somatic cell count versus parity number. Means with the same letter are not significantly different $(P>0.05)$. 
Table 2. Least square means (LSM) and standard error (SE) of somatic cell score (SCS) and somatic cell count (SCC) for lactation stage.

\begin{tabular}{ccccc}
\hline $\begin{array}{c}\text { Lactation } \\
\text { Stage }\end{array}$ & SCS & SE & SCC & SE \\
\hline $\mathrm{I}^{1}$ & 12.551 & 0.007 & $75,013^{\mathrm{a}}$ & 12.56 \\
$\mathrm{II}^{2}$ & 12.767 & 0.006 & $87,128^{\mathrm{b}}$ & 12.55 \\
$\mathrm{III}^{3}$ & 13.003 & 0.006 & $102,613^{\mathrm{c}}$ & 12.55 \\
\hline
\end{tabular}

Rows with different superscript letter are statistically different $(P<0.05)$.

$1=6$ to 100 days. Before reaching lactation peak.

$2=101$ to 200 days. Declining milk yield period.

${ }^{3}=201$ to 365 days. Period of lower milk yield

SCS on milk fat and protein content were both positive and significant indicating that as fat and protein content increase SCS decreases.

\section{DISCUSSION}

The SCC trend showed in figure 1 significantly decreased across years, this result can be explained because SCC is a key component, national and internationally, to assess milk quality, mammary gland health and prevalence of clinical and subclinical mastitis. Also, implementation in Chile by dairy industries of milk payment schemes towards the end of 1995, where SCC was incorporated as an important variable of the final price paid to the farmer has led to raw milk reaching higher quality standards. Dairy industries offered attractive premium payment for superior quality raw milk and strong economic penalties for poor sanitary quality milk (Kruze 2003).

Other studies have also concluded that SCC has diminished across years after consistent actions in several aspects were taken, such as legislation, raw milk quality payment, education/training (Agüero 2002, Lukas et al 2005, Pinedo and Meléndez 2010). Statistics of some southern Chile dairy industries showed that average SCC diminished from 460,000 to 330,000 cell/ $/ \mathrm{mL}$ from 1997 to 2000 (Kruze 2000). In the present study, the lowest SCC were recorded in the last 6 years (figure 1), this can be a consequence of the raw milk payment schemes imposed by diary industries in Chile where heavy economic penalties were given to milk that is below the minimum quality standards. Werner (2014), from a database of 640,249 lactations from 659 farms in southern Chile, from 2001 to 2011 , reported that average SCC was $161,131 \mathrm{cell} / \mathrm{mL}$ of milk, this is similar to what is reported in this study for 2017 where the raw SCC average was $151,518 \mathrm{cell} / \mathrm{mL}$ (table 1). This study used test day records up to 2017 while the study of Werner (2014) included lactations records only up to 2011, other studies using Chilean dairy records (Pinedo and Meléndez 2010) are even older.

Ponce (2009) and Romero et al (2018) suggested that in order to improve milk quality and continuing lowering SCC, more consistent farmer training and use of information technology is needed and they must reach the dairy sector, mainly small-scale producers. Also, the infrastructure of dairy companies must improve and new ways to industrialize dairy products, that are consumer safe, must be developed.

In this study, including 11 herds and across 20 years, the recorded SCC was always below European Union quality parameters that stand below $400,000 \mathrm{cell} / \mathrm{mL}$ of milk. However, in the next years, this international parameter is expected to diminish because in Australia and Scandinavian countries the national SCC average varied from 200,000 to $250,000 \mathrm{cell} / \mathrm{mL}$ (More 2009). Also, SCC above 200,000 cell $/ \mathrm{mL}$ is an indication of subclinical mastitis and consequently lower milk yield and quality and economic losses (Barbosa et al 2002, Coldebella et al 2004, Magalhães et al 2006). Philpot (1999) indicated that, above 200,000 cell $/ \mathrm{mL}$, for each 100,000 cell $/ \mathrm{mL}$ of increment of SCC milk yield decreases by $2.5 \%$.

Results shown in figure 2 indicate that SCC increases as parity number does, which is similar to that reported by Tineo and Andía (2017) ${ }^{1}$, who studied the association between mastitis and parity number and found that higher SCCs were for cows in their third and above lactations. Also, Chacón et al (2006) concluded the same, stating that as parity numbers increase so does SCC. García (2004) ${ }^{2}$ indicates that the association between parity number and SCC can be explained, from a productive point of view, because as productive life occurs there is an increment in mastitis incidence that in turns increases SCC, resulting in yield losses associated to both mastitis and SCC. In this study, the lowest SCC was observed in first lactation cows, parity number and age are highly correlated variables, therefore, first lactation cows are still growing and developing their mammary system, consequently have lower milk yield and SCC (Parra-Bracamonte et al 2005). Kirk (1984) indicates that older cows tend to have higher SCC, and age is not the only responsible factor, the prevalence of chronic udder infections is related to age and therefore the main cause of higher SCC.

Chacón et al (2006) and Castillo et al (2017) indicated that cows in first and second lactation have SCC below 200,000 cell $/ \mathrm{mL}$, however, there is an increment of SCC from the third lactation, which matches productive peak yield. Ahmadzadeh et al (2009) reported similar results than those presented in this study suggesting that, as parity number increases, there is greater exposure to pathogens

1 Tineo J, Andía V. 2017. Mastitis bovina por recuento de células somáticas con PortaSCC® y Test de California en el fundo de Allpachaca. Revista Electrónica de Veterinaria 18, 1-13. https://www. redalyc.org/articulo.oa?id=63652580009. Accessed February 2019.

2 García AD. 2004. Células somáticas y alto recuento bacteriano ¿cómo controlarlos? http://openprairie.sdstate.edu/extension_extra/537. Accessed May 2019. 
due to the interaction among healthy and diseased cows, as herd life progresses.

SCC increased with days in milk (table 2) similar to that reported by Alvarado (2006) who observed that SCC was low before 100 days in milk, this coincides with lactation Stage I of this study and, as days in milk progressed SCC increased, same as reported in this work. Stage III of lactation had the highest SCC similar to the results of Butendieck (1997), who reported higher SCC toward the end of the lactation, however, the same author also found high SCC at the very beginning of the lactation, and explaining this fact as a biological immunological preparation of the cow for calving.

The increase of SCC toward the end of the lactation is associated to a greater pathogen exposure due to a more frequent interaction among healthy and diseased cows, in addition, as days in milk progress, udder manipulation and opening of the teat duct may facilitate bacteria entrance and multiplication that leads to higher SCC (Ruegg and Pantoja 2013).

Results of this study show that the time of the year, when a test day record is gathered, has a significant effect on SCC. The coldest season recorded lower SCC, and this is in agreement with Correa-Calderón et al (2002), Alvarado (2006) and La Manna et al (2014) who found that cows exposed to low environmental temperature and/or ventilation had lower SCC and higher milk yields as compared to cows exposed to high environmental temperature and/or humidity. The increment of SCC observed in the summer months can be explained by the fact that environmental temperature and humidity are ideal conditions for bacterial growth and these, added to cow heat stress, may end up in cows suffering subclinical mastitis.

Milk yield as a covariable for SCS was statistically significant, the association was negative and, per each additional $\mathrm{kg}$ of milk the SCS decreased in 0.049. Similar conclusion was reached by Werner (2014) and Pinedo and Meléndez (2010) who found a negative association between SCS and milk yield also, Hagnestam et al (2007) described that cows, in their first lactation, with higher RCS had up to $9 \%$ lower milk yield as compared to low RCS cows. These results agree with the fact that if SCC increases, it is mainly due to an udder injury, a possible subclinical mastitis, which immediately decreases milk yield. Another reason for this negative association is due to that after lactation peak, milk yield declines and somatic cell production can remain constant then a larger SCC concentration can be detected toward the end of the lactation. Sneddon et al (2015) estimated genetic parameters for milk components in New Zealand dairy cows and reported an estimated genetic correlation, between milk yield and SCS, equal to cero $(-0.16 \pm 0.15)$.

The association described in this study between milk solids (fat and protein) and SCS reveals that as fat and/ or protein content increases SCS also does, regression coefficients of SCS on fat and protein percentage were $0.067 \pm 0.004$ and $0.419 \pm 0.010$, respectively. Werner (2014) researched the association between SCS and milk fat and protein yield and concluded that they were not significantly associated. However, at the genetic level, Sneddon et al (2015) reported a genetic correlation of $0.22 \pm 0.14$ between SCS and milk fat percentage.

It is concluded that there is a significant and positive effect of test year on SCC; as years went by the SCC decreased, consequently raw milk quality in Los Ríos region, as a result of hygienic and sanitary norms being met, improved in the last 20 years. Older cows are prone to higher SCC as well as cows in their late days in milk. Test day records gathered in summer months are likely to have higher SCC.

\section{ACKNOWLEDGEMENTS}

The first author would like to give special thanks to the Agencia Chilena de Cooperación Internacional para el Desarrollo (AGCID) and the Instituto de Ivestigação Veterinária (IIV) of Angola for their financial support to accomplish this study. The authors also thank the referees of the manuscript for their collaborative and helpful inputs to improve the final quality of this paper.

\section{REFERENCES}

Agüero H. 2002. Calidad de leche en la X Región. In: Agüero H (ed). Seminario Internacional Avances en Control de Mastitis y Mejoramiento de la Calidad de Leche. Universidad de Chile y Cooprinsem, Santiago, Chile.

Ahmadzadeh A, Frago F, Shafii B, Dalton DC, Price WJ, et al. 2009. Effect of clinical mastitis and other diseases on reproductive performance of Holstein cows. Anim Reprod Sci 112, 273-282.

Ali AKA, Shook GE. 1980. An optimum transformation for somatic cell concentration in milk. J Dairy Sci 63, 487-490.

Alvarado D. 2006. Algunas variables climatológicas y ambientales y su relación con el recuento de células somáticas en la leche de estanques prediales en la provincia de Bío Bío, Chile. Tesis, Universidad de Concepción, Chillán, Chile.

Barbosa CP, Benedetti E, Ribeiro SCA, Guimaraes EC. 2002. Relação entre contagem de células somáticas (CCS. e os resultados do "California Mastitis Test"(CMT), no diagnóstico de mastite bovina. Bioscience Journal 18, 93-102.

Brito JFF, Caldeira GAV, Verneque RS, Brito MAVP. 1997. Sensibilidade e especificidade do "California Mastitis Test" como recurso diagnóstico da mastite subclínica em relação à contagem de células somáticas. Pesquisa Veterinária Brasileira 17, 49-53.

Butendieck N. 1997. Células somáticas, mastitis y calidad de leche. In: Calidad de leche e interpretación de resultados de laboratorio. Curso - Taller. Serie Carillanca $N^{o}$ 62. INIA, CRI Carillanca, Temuco, Chile, Pp 15-32.

Carrillo B, Vidal C. 2002. Los esquemas de pago de leche en Chile. Centro de Economía Rural de Frutillar (CER) y Fundación Chile, Puerto Varas, Chile, Pp 1-14.

Castillo-Umaña AM, Alpizar-Naranjo A, Padilla-Fallas J, Keim J. 2017. Efecto de la edad a primer servicio, número y época de parto sobre el comportamiento de la curva de lactancia en vacas jersey. Nutrición Animal Tropical 11, 1-22.

Chacón A, Jiménez R, Vargas RC. 2006. Incidencia en el conteo de células somáticas de un sellador de barrera (yodo-povidona 0,26\%) y un sellador convencional (yoduro 0,44\%). Agronomía Mesoamericana 17, 207-212. 
Coldebella A, Machado PF, Demétrio CGB, Ribeiro-Júnior PJ, Meyer PM, et al. 2004. Contagem de células somáticas e produção de leite em vacas holandesas confinadas. Revista Brasileira de Zootecnia 33, 623-634.

Correa-Calderón A, Avendaño-Reyes L, Rubio-Villanueva A, Dennis V, Armstrong J, et al. 2002. Effect of a cooling system on productivity of Holstein cows under heat stress. Agrociencia 36, 531-539.

Costa HN, Molina LR, Lage CFA, Malacco VMR, Facury Filho EJ, et al. 2017. Estimativa das perdas de produção leiteira em vacas mestiças Holandês x Zebu com mastite subclínica baseada em duas metodologias de análise. Arquivo Brasileiro de Medicina Veterinária e Zootecnia 69, 579-586.

Curbelo R. 2007. Relación entre los recuentos de células somáticas, prácticas de manejo y patógenos causantes de mastitis en rebaños lecheros de Puerto Rico. Tesis, Universidad de Puerto Rico, Puerto Rico.

Fox L. 2009. Prevalence, incidence and risk factors of heifer mastitis. Vet Microbiol 134, 82-88.

Hagnestam C, Emanuelson U, Berglund B. 2007. Yield losses associated with clinical mastitis occurring in different weeks of lactation. $J$ Dairy Sci. 90, 2260-2270.

Hernández R, Bedolla C. 2008. Importancia del recuento de células somáticas en la calidad de la leche. Revista Electrónica de Veterinaria 9, 1-34.

International Dairy Federation. 1997. Recommendations for presenting of mastitis related data. IDF Bulletin 321, Brussels, Belgium, Pp 7-25.

Kirk JH. 1984. Programmable calculator program for linear somatic cell scores to estimate mastitis yield losses. J Dairy Sci 67, 441-443.

Kruze J. 2000. Milk quality in Chile: Progress towards reducing SCC and TBC in raw milk during the last twenty years. Pacific Congress on Milk Quality and Mastitis Control, 13-16 November, Nagano, Japan., Pp 113-118.

Kruze J. 2003. Evolución de la calidad higiénica de la leche cruda en los últimos 10 Años. III Seminario: Calidad de leche, Osorno, Chile, Pp 11-17.

Kruze J. 2005. Milk production and mastitis control in emerging dairy countries: The experience in Chile. In: Hogeveen $\mathrm{H}$ (ed). Mastitis in dairy production. Wageningen Academic Publishers, Wageningen, The Netherlands. Pp 123-128.

La Manna A, Román L, Bravo R, Aguilar I. 2014. Estrés térmico en vacas lecheras: con sombra y bienestar las vacas producen más. Revista INIA 39, 34-39.

Lukas JM, Hawkins DM, Kinsel ML, Reneau JK. 2005. Bulk tank somatic cell counts analysed by statistical process control tools to identify and monitor subclinical mastitis incidence. J Dairy Sci 88, 3944-3952.

Magalhães HR, El Faro L, Cardoso VL, Paz CCP, Cassoli LD, et al. 2006. Influência de fatores de ambiente sobre a contagem de células somáticas e sua relação com perdas na produção de leite de vacas da raça Holandesa. Revista Brasileira de Zootecnia 35, 415-421.

McDougall S, Parker KI, Heuer C, Compton CWR. 2009. A review of prevention and control of heifer mastitis via non-antibiotic strategies. Veterinary Microbiology 134, 177-185.

More SJ. 2009. Global trends in milk quality: implications for the Irish dairy industry. Irish Vet $J$ 62, 5-14.

National Mastitis Council. 2013. 52 ${ }^{\text {nd }}$ Annual Meeting. NMC, San Diego, California.

Nyman AK, Emanuelson U, Gustafsson AH, Persson KW. 2009. Management practices associated with udder health of first-parity dairy cows in early lactation. Prev Vet Med 88, 138-149.

Parra-Bracamonte G, Magaña J, Delgado R, Osorio-Arce M, SeguraCorrea J. 2005. Genetic and non-genetic effects on productive and reproductive traits of cows in dual- purpose herds in south eastern Mexico. Genet Mol Res 4, 482-490.

Philpot N. 1999. Aumento de la rentabilidad mediante el mejoramiento de la calidad de leche y la reducción de la mastitis. Curso de Perfeccionamiento Mejoramiento de la Calidad Higiénica de Leche de Pequeños Productores, 6-8 Diciembre, Osorno, Chile.

Pinedo PJ, Meléndez P. 2010. Patrones temporales de recuento de células somáticas, grasa, proteína y nitrógeno ureico en leche de estanque y su asociación con fertilidad en ganado lechero en la zona centro-sur de Chile. Arch Med Vet 42, 41-48.

Ponce P. 2009. Un enfoque crítico de la lechería internacional y cubana. Rev Salud Anim 31, 77-85.

Romero PA, Calderón AR, Rodríguez VR. 2018. Evaluación De La Calidad De Leches Crudas En Tres Subregiones Del Departamento De Sucre, Colombia. Revista Colombiana De Ciencia Animal 10, 43-50.

Ryman VE, Packiriswamy N, Sordillo L M. 2015. Role of endothelial cells in bovine mammary gland health and disease. Anim Health Res Rev 16, 135-149.

Ruegg PL, Pantoja JCF. 2013. Understanding and using somatic cell counts to improve milk quality. Irish J Agric Food Res 52, 101-117.

Santos MV. 2006. O uso da CCS em diferentes países In: Mesquita AJ, Durr JW, Coelho KO (eds). Perspectivas e avanços da qualidade do leite no Brasil. Editora Talento, Goiânia, Brazil, Pp 181-197.

SAS, Statistical Analysis System. 2000. SAS version 6.0. SAS Institute Inc., Cary, NC, USA.

Sneddon NW, Lopez-Villalobos N, Davis SR, Hickson RE, Shalloo L. 2015 Genetic parameters for milk components including lactose from test day records in the New Zealand dairy herd. New Zeal $J$ Agric Res 58, 97-107.

Werner EG. 2014. Relación de la producción de leche y calidad sobre el recuento de células somáticas en rebaños del sur de Chile. Tesis, Universidad Austral de Chile, Valdivia, Chile. 
